\title{
Comparison of Simple Additive Weighting (SAW) and Promethee Methods in Rice Quality Selection
}

\author{
Fatma Sari Hutagalung1, Budi Kurniawan Hutasuhut², Al-Khowarizmi3 \\ 1,2,3 Department of InformationTechnology, Universitas Muhammadiyah Sumatera Utara, Indonesia
}

\begin{abstract}
Rice is one of the foods that contain enough nutrients and boosters for the human body, because it contains ingredients that are easily converted into energy. In Indonesia there are more than 1000 types of rice varieties, and every year new varieties appear. Farmers find it difficult to determine which type of rice they will plant. Farmers must try each type of different varieties each season, to find out which quality rice. For this reason, a decision support system is needed to select qualified rice. In the decision support system two methods of comparison are used, namely the Simple Additive Weighting (SAW) method and PROMETHEE. The Simple Additive Weighting (SAW) method will be compared to the PROMETHEE method. In a decision support system, the data used will be changed first into the form of weights that have been determined based on parameters. The types of rice used are paddy and hybrid rice. Both methods will be compared based on the length of time of execution and the success rate of selecting rice quality. The end result of the system for rice using both methods is the angke for lowland rice and the 6 ceva hipa for hybrid rice. with an execution time of 570,0008 milliseconds for the SAW method, and PROMETHEE method with an execution time of 12488.2 milliseconds in lowland rice, and 1140,006 milliseconds for the duration of SAW execution, 16400,029 for the duration of PROMETHEE for hybrid rice. The SAW method is faster than the promethee method.
\end{abstract}

Keyword : Decision support system, simple additive weighting (saw), promethee

Corresponding Author:

Fatma Sari Hutagalung,

Department of Information Technology,

Universitas Muhammadiyah Sumatera Utara,

Jalan Kapten Muktar Basri No 3 Medan 20238, Indonesia.

Email: fatmasari@umsu.ac.id

\section{INTRODUCTION}

Rice is one of the foods that contain enough nutrients and boosters for the human body, because it contains ingredients that are easily converted into energy. Rice is cultivated with the aim of getting the highest results possible with the best quality[1][2]. In general, each region has its own type of rice seed. Seeds are said to be of good quality if they are pure, healthy, dry, healthy, free from disease and free from undesirable mix of grass seeds. A good seed must be high in germination capacity, at least it must reach $90 \%$. Seeds with these criteria are usually able to produce plants that are healthy, well-built, sturdy, uniform growth and have good quality [3][4]. In Indonesia, more than 1,000 types of rice seeds (varieties) are known, this large number makes it difficult for farmers to decide which quality seeds they will plant.

Along with the development of information technology has made it possible to make decisions more quickly and accurately [5][6][7]. The use of computers has evolved from merely processing data or presenting information to management. This is thanks to the development of hardware technology, which is accompanied by software development, as well as the ability to assemble and incorporate several decision-making techniques into it. The integration of hardware, software, and decision processes results in a Decision Support System (DSS) that allows users to make decisions faster and more accurately. SAW method is often also known as the weighted sum method. The basic concept of the SAW method is to find a weighted sum of the performance ratings for each alternative on all attributes[8][9].

Promethee is one of the methods used to make decisions on multi criteria decision making (MCDM). The way that is often done when going to take decisions in MCDM is to compare one alternative 
with another alternative. Comparisons are made for each criterion. After the comparison process is carried out, the next process is to rank alternatives that are based on the results of the comparison process. SAW and Promethee have different basic concepts and ways of solving problems. This has encouraged the authors to make a comparison of research on the selection of rice quality, using the Simple Additive Weighting (SAW) method and the Promethee method[10][11][12].

\section{RESEARCH METHOD}

A. Analisys

The problem that will be discussed in this research is how to get quality rice yields that are in accordance with predetermined criteria by comparing the Simpe Additive Weighting (SAW) algorithm and PROMETHEE. One way to analyze problems in a study is to use Ishikawa diagrams.

Ishikawa's diagram is a tool that helps identify the cause of a problem. In the Ishikawa diagram the problem is on the right (head), the cause of the problem is described as bone as in Figure 1.

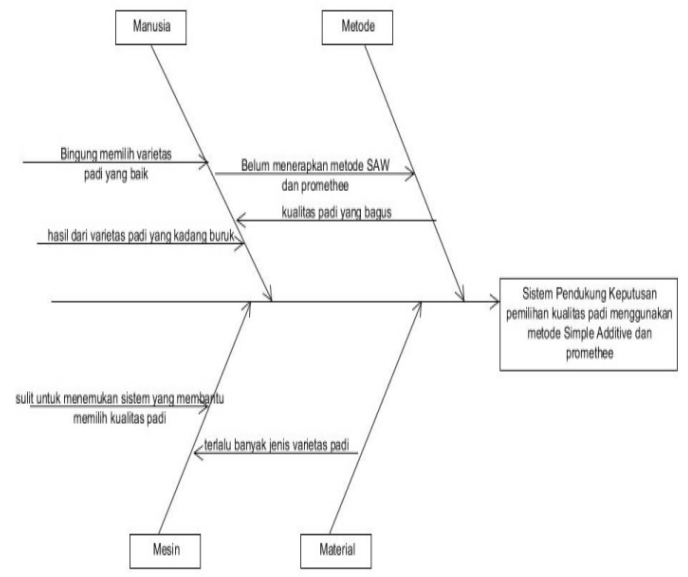

Figure 1 Ishikawa Diagram

In the Ishikawa diagram in Figure 1 explains that the problem that occurs is the confusion of farmers in choosing the types of rice varieties that they will plant, because of the many new varieties that appear each year, it is not uncommon for rice varieties that farmers grow to produce poor quality rice. It is difficult to find a system that helps in the selection of rice quality. The system was made to help farmers choose which types of rice they would plant using the Simpe Additive Weighting (SAW) and PROMETHEE methods.

In building a system it is necessary to go through the system requirements analysis stage. Analysis of system requirements is divided into 2 parts, namely functional requirements and nonfunctional requirements.

1. Functional Requirements

Is a requirement that must be owned by the decision support system for rice quality selection, namely:

a. Apply the Simple Additive Weighting (SAW) algorithm in the selection of rice quality

b. Apply the PROMETHEE algorithm in the selection of rice quality

c. The system can display the ranking results of each type of rice, and display super, premium, medium and low quality rice.

d. The system can enter data on new types of rice varieties by entering the specified rice criteria.

e. Using the running time parameter (access time in milliseconds)

2. Non-functional requirements are descriptions of activities and services that the system must provide.

The functional requirements are inputs, outputs, processes, among others:

1. The system must be able to provide a solution to the decision support system for the selection of rice quality (lowland rice and hybrid rice) by implementing the Simple Additive Weighting (SAW) algorithm.

2. The system must be able to provide a solution to the decision support system for the selection of rice quality (paddy and hybrid rice) by implementing the PROMETHEE algorithm.

3. Using the running time parameter (access time in milliseconds) to measure the work of the algorithm. 
4. In determining the comparative value of criteria and alternatives used from the agricultural extension office data.

B. Modeling

in the system modeling section, we will design how the system is expected to work later. This modeling uses UML (Unified Modeling Language).

a. Use Case Diagrams

Use case diagrams are used to illustrate the set of actions that the system must work in collaboration with one or more external users of the system (actor). The system usecase can be seen in Figure 2

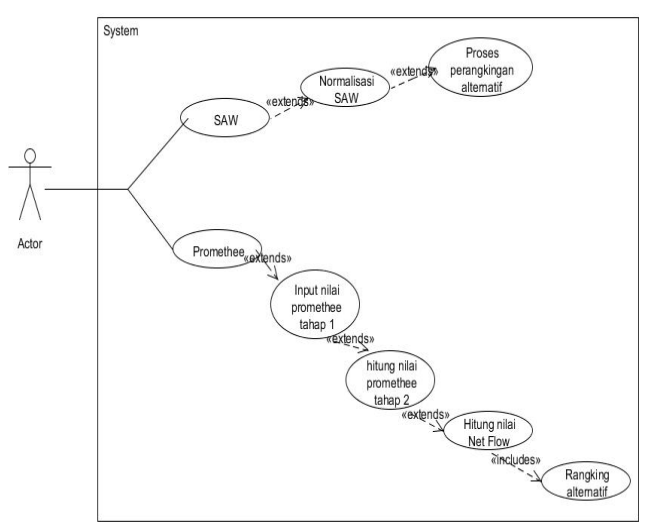

Figure 2 Use case

b. Activity Diagram

Activity diagram is a diagram that shows the flow of the control or object flow by emphasizing the order and condition of the flow. Activity diagram for this study the authors divide into 2 parts SAW and PROMETHEE as in figures 3 and 4.

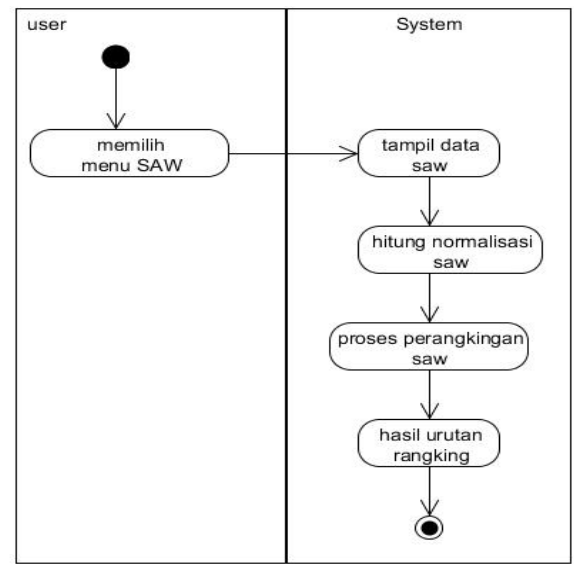

Figure 3 Activity SAW Diagram

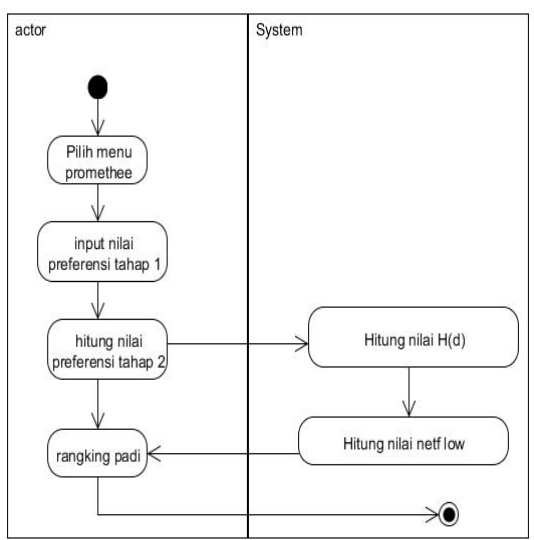

Figure 4 Activity PROMETHEE Diagram 
c. Sequence Diagram

Sequence Diagrams are interactions describing interactions between actors and systems in a use case scenario. Sequence diagrams for this study the authors divide into 2 parts, the SAW sequence diagram and the PROMETHEE sequence diagram as shown in Figures 5 and 6.

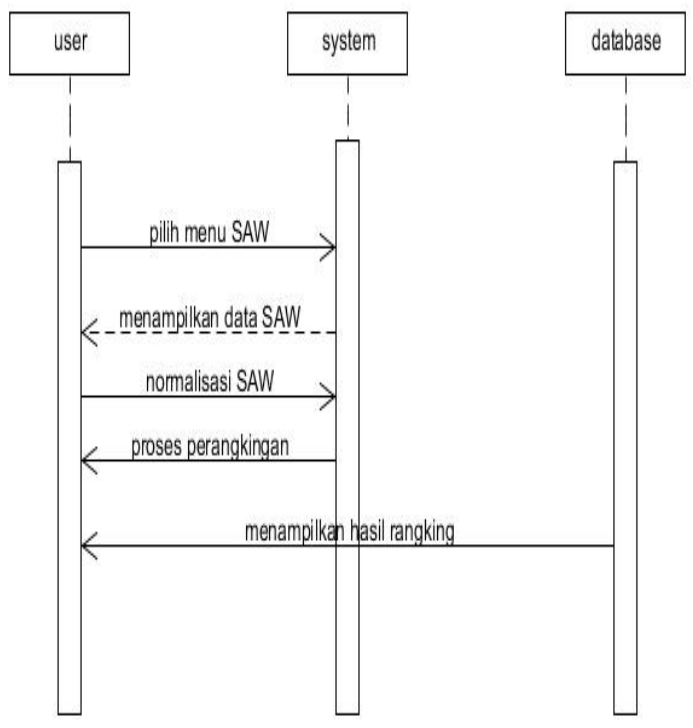

Figure 5 Sequence Diagram SAW

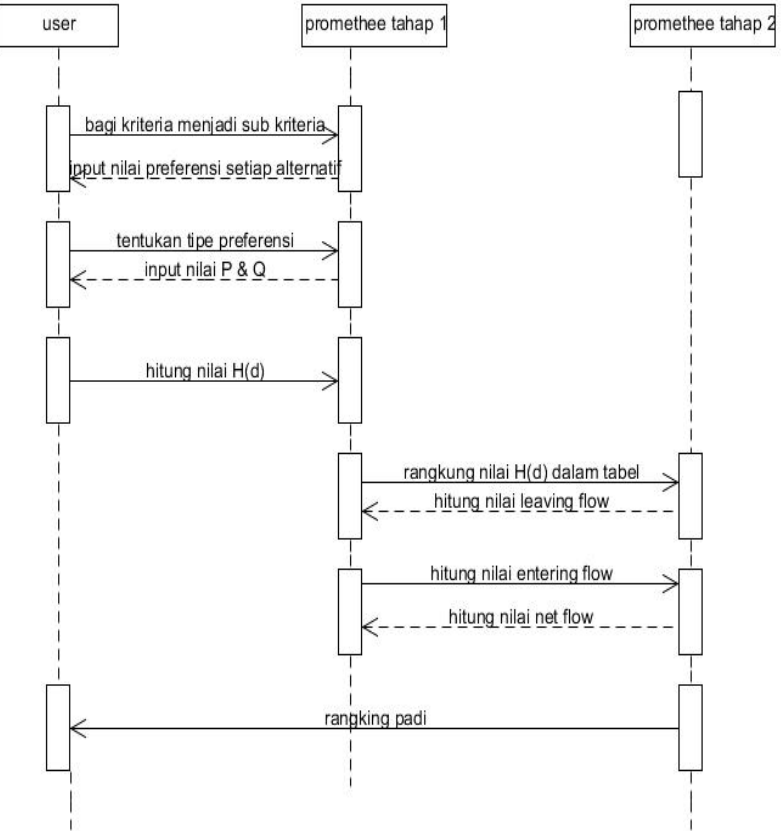

Figure 6 Sequence Diagram PROMETHEE

a. Flowchart

Flowcharts help to compile a picture of program flow so that it is easier to understand. Figures 7 and 8 are the SAW and PROMETHEE flowcharts. 


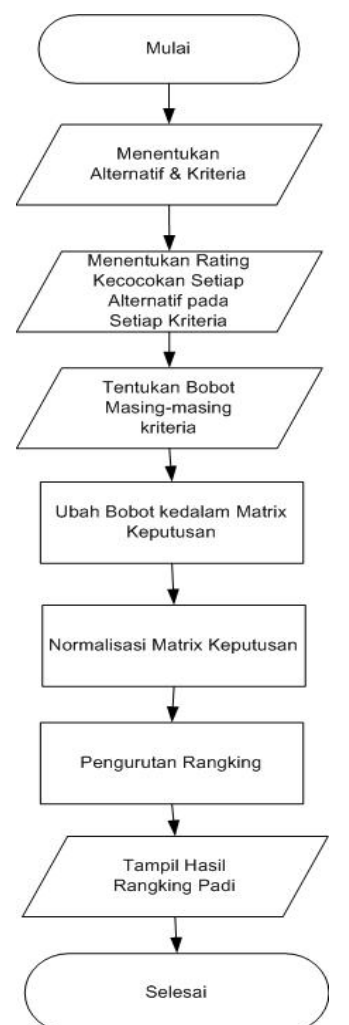

Figure 7 SAW Flowchart

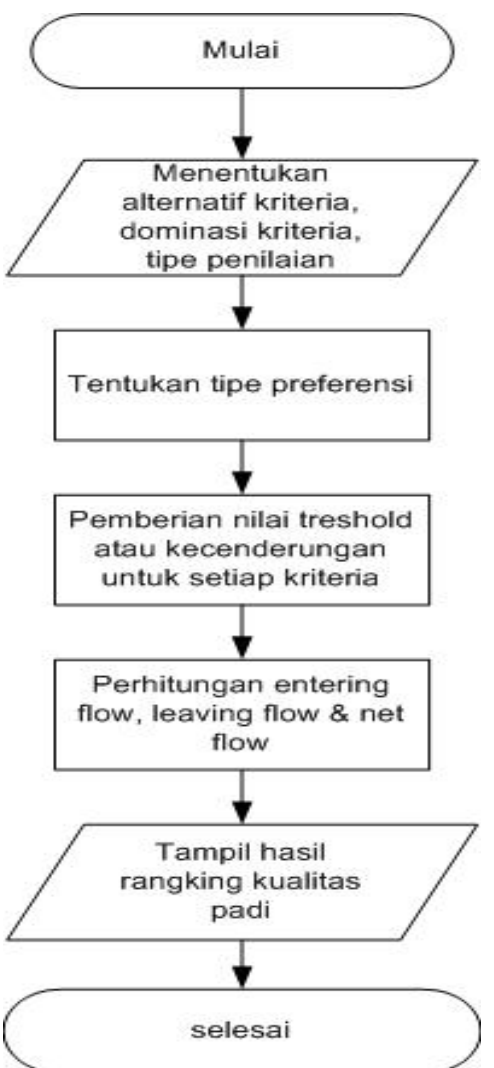

Figure 8 PROMETHEE Flowchart 


\section{RESULTS AND DISCUSSION}

The calculation process that has been carried out by the system is based on the same criteria which, then compared to the two methods, the results of comparison of testing of wet rice can be seen in Figure 9 and the comparison of hybrid rice testing in Figure 10.

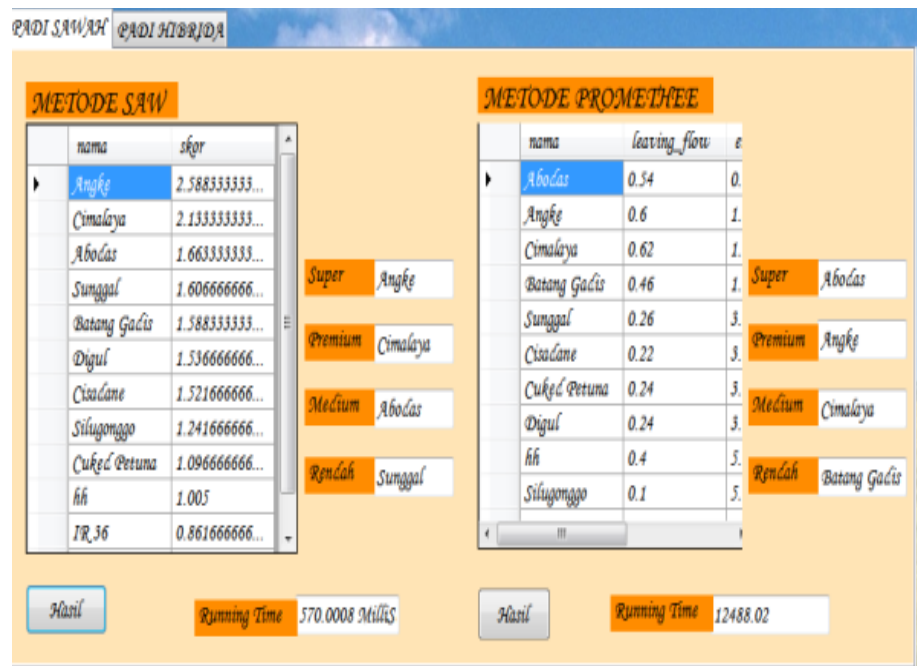

Figure 9 The results of the comparison of the SAW method and lowland rice promethee

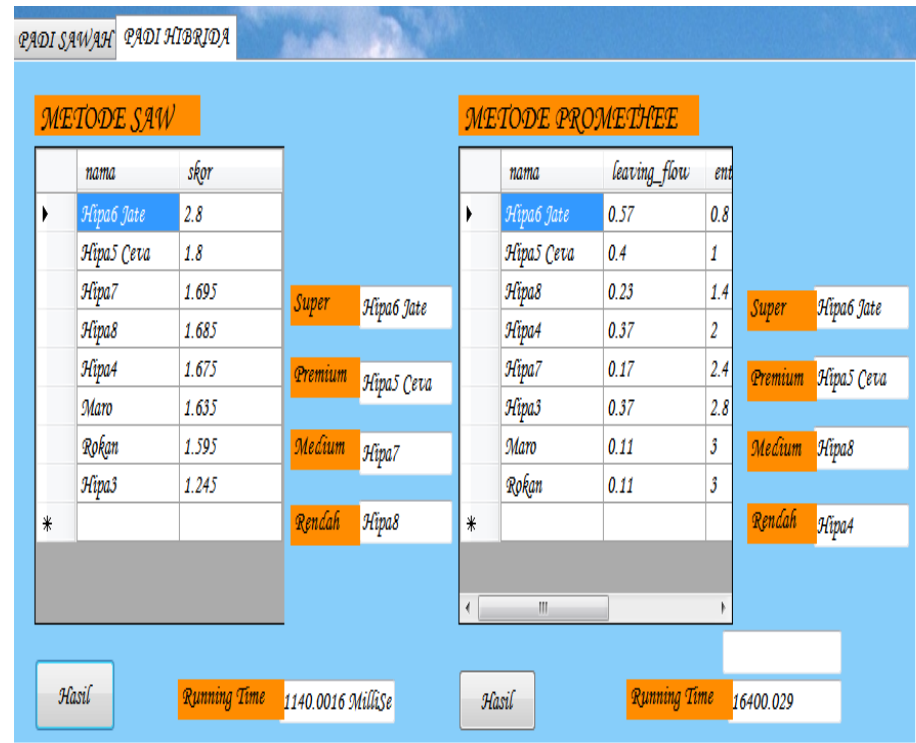

Figure 10 comparison of SAW and Promethee hybrid rice methods

\section{CONCLUSION}

After carrying out the implementation and testing stages of the decision support system to determine the quality of rice, the conclusion is that the system built can assist farmers in choosing which type of rice they will plant. Ranking the results of rice quality is based on criteria that have been determined. The weight given to each criteria influences the final ranking results. Changes in weight values will also affect the final result. Based on the running time obtained using 10 data for lowland rice, and 8 data for hybrid rice, the SAW method with an execution time of 570,0008 milliseconds and the method of promethee with an execution time of 12488.2 milliseconds in lowland rice, and 1140,006 milliseconds for the long execution time SAW, 16400,029 for the duration of the promethee execution on hybrid rice. The SAW method is faster than the promethee method. 


\section{REFERENCES}

[1]. Andoko, A. 2010. Budidaya Padi Secara Organik. Penebar Swadaya . Jakarta.

[2]. Ariansyah,sigit . Aknuranda, Ismiarta . Rachmadi , Aditya. Sistem Pendukung Keputusan Evaluasi Kinerja Penyidik Anggota Polri dengan menggugunakan Metode Promethee.(Studi Kasus: Direktorat Reserse Kriminal Umun Polda Jatim Surabaya) . Jurnal. Universitas Brawijaya. Malang . pp : 2-4 .

[3]. Amrizal, Yusuf. Akmal. \& Catur Hermanto. 2013 Pendekatan Pengolahan Tanaman Terpadu Pada Pendampingan Sektor Pembenihan. Balai Pengkajian Teknologi Pertanian Sumatera Utara. Medan.

[4]. Islami, Dini . 2014 . Analisis Kelayakan Kredit Kepemilikan Rumah Dengan Metode Profile Matching dan Promethee (Studi kasus CV. Karya Bersama ) . Skripsi.Universitas Sumatera Utara .

[5]. Kusrini. 2007. Konsep dan Aplikasi Sistem Pendukung Keputusan. CV.Andi: Yogyakarta.

[6]. Kusumadewi, Sri . 2006. Fuzzy Multi-Attribute Decision Making (Fuzzy MADM). Graha Ilmu,Yogyakarta. Lumbantoruan, H.C. 2014.

[7]. Sistem Pendukung Keputusan Menentukan Biji Kopi Berkualitas Ekspor Dengan Metode Simple Additive Weight (SAW). (Studi Kasus : PT. Volkopi Indonesia Lintongnihuta Humbang Hasudutan) ISSN : 2301-9425. Jurnal . STMIK Budi Dharma, Medan . pp : 64 .

[8]. Novaliendry, Dony . 2009. Aplikasi PenggunaanMetode Promethee dalam Sistem Pendukung Keputusan untuk Penentuan Media Promosi. Jurnal Ilmiah. Universitas Negeri Padang . pp : 105-107.

[9]. Pradita, Ranida. Hidayat, Nurul. 2013. Sistem Pendukung Keputusan Pemilihan Guru Berprestasi Menggunakan Metode Promethee. Jurnal Sains dan Seni Pomits Vol2, No.1. Institut Teknologi Sepuluh November Surabaya . pp : 2-3.

[10]. Lubis, A. R., Prayudani, S., Lubis, M. \& Al-Khowarizmi. (2019). Analysis of the Markov Chain Approach to Detect Blood Sugar Level. In Journal of Physics: Conference Series (Vol. 1361, No. 1, p. 012052). IOP Publishing

[11]. Romidhoni , Fery. Sagirana, Tri. Amelia, Tan . Sistem Pendukung Keputusan Pemberian Beasiswa Menggunakan Metode Simple Additive Weighting (SAW) di Universitas Panca Marga Probolinggo. Jurnal . Sistem Informasi. Sekolah Tinggi Manajemen Informatika \& Teknik Komputer Surabaya. pp: 5.

[12]. Sinaga, Teti . 2014. Sistem Pendukung Keputusan Untuk Menentukan Peminjaman dan Besar Peminjaman Dana PNMP Mandiri dengan Kombinasi Metode Multivactor Evaluation Process (MEV) dan Weighted Product (WP) . (Studi Kasus Desa Hutagalung, Kec : Harian, Kabupaten : Samosir ) . Skripsi . Universitas Sumatera Utara. 